\title{
Accusing Russia of Fascism
}

\section{Polemics around Russia's Belonging to Europe}

\author{
Marlene Laruelle
}

\author{
Marlene Laruelle \\ Institute for European, Russian and Eurasian Studies (IERES) \\ Research Professor, Director \\ Web of Science ResearcherID: AAN-1443-2020 \\ International Standard Name Identifier: http://isni.org/isni/0000000119469413 \\ E-mail: laruelle@gwu.edu \\ Address: George Washington University, 1957 E Str., NW, Suite 412, Washington, D.C. 20052, USA \\ https://orcid.org/0000-0001-8289-2695 \\ DOI: $10.31278 / 1810-6374-2020-18-4-100-123$
}

\begin{abstract}
With memory wars between Central and Eastern European states and Russia, the Second World War has become a useable past instrumentalized as a currency for legitimacy on the international scene. These memory wars focus on who was fascist and who colluded with Nazism-the Soviet Union between 1939 and 1941 or the collaborationist forces in Central and Eastern Europe? And, subsequently, who are the new fascists advancing a revisionist interpretation of the Second World War today: Putin's Russia or Central and Eastern European countries? What is at stake here is the recognition of Russia as having a legitimate say in European affairs because of the Soviet victory, or its exclusion for refusing to repent of its role in dividing Europe and occupying a part thereof. This article debunks the accusation of fascism attributed to Putin's regime and offers to look at the label of fascism as a mirror game between the West and Russia in defining what Europe should be like and Russia's inclusion or exclusion.
\end{abstract}

Keywords: Russia, Europe, fascism, memory wars, Second World War. 


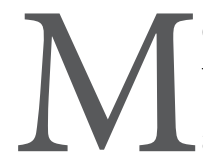
emory wars around the interpretation of the Second World War/Great Patriotic War continue to rage between Central and Eastern European countries and Russia, with European institutions being hostage to these conflictual narratives. The recent blunt statements made on all sides, for instance by Polish President Andrzej Duda, Ukrainian President Vladimir Zelensky, and Russian President Vladimir Putin, with regard to the 75th anniversary of the liberation of Auschwitz, encapsulate the meaning of the Second World War as a currency on the international scene.

What is at stake is the recognition of Russia as having a legitimate say in European affairs because of the Soviet victory, or its exclusion for refusing to repent of its role in dividing Europe and occupying a part thereof. Did Moscow win the war in 1945, and should it thus be celebrated for the huge human cost of this victory? Or did it contribute to the start of the war by signing the Ribbentrop-Molotov Pact of 1939 that allowed it to occupy parts of Poland and Finland, and then annex the Baltic states? These memory wars focus on who was fascist and who colluded with Nazism - the Soviet Union between 1939 and 1941 or the collaborationist forces in Central and Eastern Europe? And, subsequently, who are the new fascists advancing a revisionist interpretation of the Second World War today: Putin's Russia or the Central and Eastern European countries?

Since the mid-2000s, accusing Russia of being fascist has become a central narrative among Central and Eastern European countries, as well as among some Western policy figures, such as former U.S. National Security Advisor Zbigniew Brzezinski (2004), former CIA Director James Woolsey (RFE/RL, 2005), former U.S. Secretary of State Hillary Clinton (Rucker, 2014), and so on. This accusation has also grown-very moderately so far-in the academic world, supported by such scholars as Timothy Snyder, Alexander Motyl, Vladislav Inozemtsev, and seconded by several Russian political opponents to the Putin regime (Garry Kasparov, Yevgeny Ikhlov, and Lev Slosberg). At stake is not only the academic debate; labeling has direct policy implications: charging Russia of being fascist implies that the country has exited the international community and cannot be considered a 
legitimate partner. If "Putin is Hitler," as some profess, who would want to negotiate with him and try to rebuild a constructive dialogue with Russia?

Two narratives thus collide directly: one asserting that Russia is a fascist country (or that at least its leaders are fascist), and the other one defining Russia as a country that defeated fascism. Unfortunately for all those who hope for a black-and-white vision of the world, historical realities are more complex. The Soviet Union can be responsible for taking advantage of an agreement with Hitler in 1939 while also being victorious against Nazi Germany in 1945.

To disentangle the puzzle, where so many actors accuse each other of the same evil and where insulting labels and academic terminology interact with intentional semantic obfuscation, I take my cue from semiotics, namely from understanding words as communicative tools, or signs, that are embedded in and shape our everyday meaningmaking (Wodak et al., 1999). Like any other word, "fascism" is a communicative tool based on an implicit cultural background that makes it possible for the audience to interpret the term; it is a constructed notion expressing a relational situation. As early as 1946, George Orwell observed in Politics and the English Language that "fascism has now no meaning except in so far as it signifies something not desirable" (Orwell, 1946).

I argue here that "fascism" has become one of Russia’s strategic narratives, operationalized at two levels. At home it is used to generate cultural consensus around the memory of the Great Patriotic War in favor of the regime's status quo. On the international scene, it is deployed to upgrade or at least stabilize the country's status as having a legitimate say in European security thanks to the 1945 victory. By calling its enemies "fascists," the Russian regime describes its own understanding of the international system, offering a storyline that puts the Russian people and its values and goals at the center of the plot. Another strategic narrative, ideologically opposite but performing exactly the same function, is displayed by all those who label Russia as fascist. This accusation performs the simple role of reducing Russia to being Other than the West, embodying everything that is not desirable for the West. 
While the study of Russia has long been molded by outdated binariesdemocracy/authoritarianism, West/non-West, Europe/Asia, etc.the new line of divide between Russia's supposed fascism versus the West's supposed liberalism only contributes to adding one more black-and-white pair with a very limited heuristic value. Based on my forthcoming book, Is Russia Fascist? Unraveling Propaganda East West (Cornell University Press, 2021 [forthcoming]), this article debunks the accusation of fascism attributed to Putin's regime and offers to look at the label of fascism as a mirror game between the West and Russia in defining what Europe should be like and considering Russia's inclusion or exclusion.

\section{DECONSTRUCTING HISTORICAL ANALOGIES}

Yale Professor Timothy Snyder has been one of the most vocal promoters of the thesis that Russia is fascist. He advanced this idea in a series of op-eds published in The New York Times and The New York Review of Books, and then in his book Road to Unfreedom: Russia, Europe, America. Abusing historical parallels, Snyder uses a simplistic labeling technique, and deploys reductive explanatory frameworks. He affirms, for instance, that the Russian regime has rehabilitated the Ribbentrop-Molotov Pact, which is a shortcut in analysis. The Russian state's grand narrative about the Pact, including Putin's latest piece, "The Real Lessons of the 75th Anniversary of World War II," published in The National Interest in June 2020, pursues the tradition of equating the Pact with the Munich Agreement. For Russia, the aim is to refute the Soviet Union's sole responsibility for Europe's total war and to insist on Western countries' shared role: Western Europe abandoned Central Europe to its destiny with the Munich Agreement; the Pact should therefore be understood in such an ambivalent context.

Secondly, Snyder suggests that the Kremlin's support for the European far right is a continuation of Stalin's alliance with Hitler, aimed at destroying the European world order. This attempted historical parallel does not hold for several reasons. Firstly, seeing today's far right as the direct heir of Nazism is a shortcut disqualified by all scholars working on far-right renewal (Mudde, 2019; Camus 
and Lebourg, 2017). Moreover, waves of illiberalism in Hungary and Poland, two countries whose populations have historically been shaped by an anti-Russian stance, demonstrate that Moscow cannot be blamed for the growing skepticism of European public opinion-this is a home-grown, deeply rooted phenomenon that is much more complex than a mere import from Russia.

A third set of arguments advanced by Snyder relates to White reactionary thinker Ivan Ilyin's alleged role in Putin's ideology. Although Ilyin has been held up as the ideological inspiration for the pro-White factions in Russia (for instance, Nikita Mikhalkov), it would be a mistake to claim that he is Putin's main doctrinal reference (Laruelle and Karnysheva, 2020). The Russian president did not show him special deference by visiting his grave in 2009: he was also visiting Nobel Laureate Alexander Solzhenitsyn's one. Putin has quoted Ilyin on five occasions, but this cannot be taken as proof of influence: he has quoted Eurasianist thinker Lev Gumilev six times and regularly refers to many other Russian thinkers and historians, from Karamzin to Berdyaev. Moreover, all of those quotations mirror the conventional framing of Russia, its culture, and the role of the state; none are related to Ilyin's most controversial anti-Semitic statements supportive of Nazi Germany or fascist Italy. When Ilyin's writings are brought into the Kremlin's pantheon, it is thus in support of mainstream statements about Russia that could have been stated by many other Russian thinkers. Furthermore, Snyder has obscured the many occasions on which Ilyin's positions have appeared in fundamental opposition to Putin's: rehabilitating his writing as a whole would mean embracing too many ideological components with which the Kremlin cannot agree.

Last but not least, Snyder accuses Putin of having justified the annexation of Crimea by reference to Germany's "changing borders" doctrine, implying that Putin openly compared his actions to those of Nazi Germany (Snyder, 2014). This is a gross and unfair accusation. Putin's speech very clearly refers to German reunification in 1990, not the Anschluss or the annexation of the Sudetenland (Putin, 2014). This does not, of course, justify the annexation of Crimea, but it does 
demonstrate that Putin's reference was to German reunification, not to the actions of Nazi Germany. Moscow's standard of normalcy is the Cold War, not the Molotov-Ribbentrop era. The Kremlin does not live in an ideological world inspired by Nazi Germany, but rather in one in which the perestroika years, the collapse of the Yalta order, and the breakup of the Soviet Union still constitute the main historical referents and traumas.

Exaggerating the alleged meaning of historical analogies by associating every decision taken by Putin's Russia with Nazi Germany only confuses the issue, instrumentalizing a "useable past" to sling mud at Russia and restrict the use of other analytical tools. In a fruitless detour, Snyder even tried to blame Ilyin's ideological stance for the Kremlin's meddling in the 2016 U.S. presidential election (Snyder, 2016), and, of course, to see Russia's direct influence in Donald Trump's victory (Pinkham, 2018).

\section{THE NEO-TOTALITARIANISM FALLACY}

Another aspect of the debate to be debunked is related to the use of the concept of totalitarianism. The concept is instrumentalized to support what is in fact a fallacious logical triangle: if Nazism and Communism are equally totalitarian and if the Putin regime is neo-Stalinist, then Putin's Russia equals Nazism through its revamped Stalinism. But the triangle does not withstand scholarly analysis. If Nazism and Stalinism do share a lot of similar state violence practices, they differ in many other aspects; Communism cannot be limited to Stalin's years; and seeing the Putin regime as neo-Stalinist is more than reductionist-and further it is criticized by a large majority of political scientists working on today's Russia (see for instance Sherlock 2016).

Contrary to Alexander Motyl's claims (2016), today's Russia does not offer any criteria that would qualify it as a totalitarian state: there is no system of terror in place, no mandatory indoctrination to subjugate the masses, nor any mobilization mechanisms. Even the qualification of authoritarianism should thus be deployed with nuance in the Russian case. Obviously, public freedoms have been curbed over the last decade, the president may stay in power for life, the 
electoral options offered by political parties are limited, opponents are hampered in their expression, and the media is increasingly controlled. Yet ideological diversity is still available to those who look for it: liberal protests regularly shake Moscow and the country's big cities, and urban activism and municipal politics have shown new spaces for civil society to self-express (see Semenov, 2020; Semenov and Bederson, 2020). According to the Memorial Human Rights Center (Pravozaschitny Tsentr Memorial, n.d.), only about 54 people are considered political prisoners (to that can be added 254 people imprisoned for "religious extremism," which is a dubious category), a number that pales in comparison to dictatorial regimes such as China or to genuinely authoritarian ones like Turkey.

The Russian regime also misses another core element of fascism: mass indoctrination and mobilization. Despite this-or perhaps because of it-several Western observers have been searching for Putin's hypothetical ideological guru since the early 2000s. This role has traditionally been allotted to Alexander Dugin, whom Western experts mistakenly have credited as "Putin's brain" (Barbashin and Thoburn, 2014) because of his role in popularizing Eurasianist terminology. However, Dugin has failed to acquire any institutional status within state structures, and his theories are too esoteric to compete with the producers of more useable and less radical ideologies (Laruelle, 2018). More recently, Ivan Ilyin has been identified as Putin's ideological inspiration, first by Anton Barbashin and Hannah Thoburn (2015) and then by Timothy Snyder. Here, too, their arguments are based on a very segmented and biased interpretation of the regime's ideological fundamentals and an erroneous interpretation of those who are in fact solitary thinkers.

Not only does the Russian regime not advance any official coherent doctrine, but it also lacks what most scholars consider to be the lowest common denominator of fascism: a utopian project of transformation that operates by mobilizing the masses around the promotion of violence (Griffin, 1991). Indeed, the core elements that differentiate fascism from other reactionary ideologies based on anti-Enlightenment are the myth of regeneration and the cult of violence. Fascism does not 
aim to preserve or restore the past but instead seeks to create a radically new society. Yet Putin's regime does not exhibit any utopian features that require a total transformation of the current world order nor the aim of building a New Man. None of the official discourses appeal for a new mankind to be built. On the contrary, since the mid-2000s, and even more since Putin's third presidential term, the Kremlin's enthusiastic embrace of conservatism confirms its fear of anything that could be associated with revolutionary changes (Robinson 2019; Robinson 2020; Suslov and Uzlaner, 2019). It calls for the preservation of the existing order, hoping to achieve the laconic acceptance of the world as it is.

Furthermore, organizational elements associated with fascist utopianism are absent from contemporary Russia. The presidential party United Russia has never emerged as a structure able to enlist and indoctrinate the masses. On the contrary, it remains a party for bureaucrats and all those who wish to secure their careers, making it more akin to the Communist Party of the Soviet Union than to the Nazi or Italian fascist parties.

Only twice in two decades has the Kremlin tried to cultivate an atmosphere of mobilization in the country. The first attempt occurred between 2005 and 2008, when it mobilized youth movementsembodied by the Nashi (Lassila, 2014) - in the hope of both preempting a color revolution and structuring a vanguard that would inspire the rest of society to engage in active defense of the regime's values. The second took place at the peak of the Ukrainian crisis in the spring 2014, when the Kremlin-sponsored nationalist mobilization allowed for an atmosphere of hysteria at home and called for volunteer fighters to join the Donbass insurgency. But once some of these radical groups began calling for a "Russian Spring" to take over not only Kiev but even the Kremlin itself, the authorities became fearful of fueling revolution at home and retook control over the insurgents and the volunteer fighters (Hosaka, 2019; Laruelle, 2015).

Thus far, the Kremlin has succeeded in consolidating passive patriotism-passive support for the regime and marginalization of those forces that would contest its authority-but not an active one. 
This observation indicates that the mobilization and indoctrination typical of fascist regimes are missing from today's Russia.

\section{NO ETHNONATIONALIST DOCTRINE}

Another feature considered core to any fascist regime is ultranationalism. Needless to say, the Putin regime cannot be equated with Nazism, the core plan of which was to eliminate all races defined as inferior. The Kremlin has never promoted racial destruction or genocide. The Russian state does not even advance a doctrine of Russian ethnic superiority. ${ }^{1}$ There may be tensions, for instance, around the reduced rights given to minority languages-particularly in Tatarstan (Yusupova, 2019) - but this trend belongs more to the institutional and legislative recentralization of the regime than to an ethnonationalist repertoire that would aim to ethnically Russify the entire Federation. The Russian political and economic elites are still very multiethnic. The Muslim republics, their elites and their public opinion are among the main supporters of today's system, more than ethnic Russian urban middle classes.

Putin, as well as the main government figures, heavily insists on Russia's multinational and multi-confessional nature. The Russian president has on several occasions denounced nationalism as a danger to the country: putting one nationality above another "was the formula used by those who paved the way for the collapse of the Soviet Union" (Putin, 2012) and would fracture the union of Russia's peoples (Putin, 2015). The Russian president has maintained a policy of open borders with the member states of the Eurasian Economic Union, going directly against its own public opinion, much more xenophobic against labor migrants. The only time Putin referred positively to the term when he presented himself as "the most proper and true nationalist" was first in 2014, before repeating it at the 2018 Valdai summit. Even if the sentence also mentions the interests of the Russian people, the president used the expression as a synonym for sovereigntist and anti-globalist, doing so as a way to put his patriotism against a Western liberal order that would favor interference in domestic affairs (Putin, 2019).

On the debate over the use of the term 'russkiī', see Kolstø, 2016 and Laruelle, 2016. 


\section{RUSSIA WARMONGERING?}

Together with ultra-nationalism, warmongering is another key component of a fascist regime, for which violence is a natural regenerative mechanism. Nothing in Russia's official position in strategic and nuclear defense policy can be interpreted as promoting war as a solution to regenerate the state. The state's massive reinvestment in the army, the military-industrial complex, and nuclear deterrence mechanisms signals the failure of the post-Cold War "reset" or "détente" that has resulted in the return to an international order based on deterrence and balance. Being in an adversarial relationship with the West, especially with the United States, does not indicate a desire for conflict (Darden, 2018). Both the 2008 conflict with Georgia and the 2014 split with Ukraine were Moscow's reaction to what it interprets to be the West's willingness to change this post-Soviet order by incorporating Georgia or Ukraine into its transatlantic structures (Toal, 2019).

Marcel van Herpen's description of Russia's spheres of influence as a "hidden Lebensraum" (2013) advances another inaccurate parallel with Nazism, unequivocal in its goal of demographically conquering and destroying populations living in targeted territories. By contrast, nothing in Russia's notion of spheres of influence relates to killing local populations or sending ethnic Russians to colonize these territories. Russia instead emphasizes control over its neighbors' strategic orientation in order to avoid their membership in Western institutions such as NATO or the European Union. Moreover, since the 2006 launch of its state compatriots policy (Shevel, 2012), Moscow has been more interested in the return of Russians from the "near abroad" as a useable workforce for the country itself than in consolidating their demographic presence abroad-the Lebensraum analogy thus collapses immediately.

Furthermore, the Russian state remains careful in its relationship to irredentism: the idea of a "Russian World" cultivates fuzziness in regard to the legal relationship between Russians outside of Russia and the Russian state itself. This repertoire is mostly one of soft power or public diplomacy, centered on the promotion of Russian culture and 
history abroad, more than on systematic legal protection (Suslov, 2018; Laruelle, 2015). Support for genuine irredentist claims towards Russian minorities in Ukraine, Latvia, Estonia, or Kazakhstan-in the sense of changing borders to account for ethnic minority presence-is absent from official state policy (Knott, 2017; Laruelle, 2015).

In Russia's almost 30 years as an independent state, Crimea is the only example of concrete irredentism, a so far unique case that can be explained as the Kremlin's reaction to its loss of influence over Ukraine and its fear of losing access to Sevastopol, its main gate to the Black Sea. Here, too, Moscow's actions were reactive-the Kremlin intervened once it understood that it could not stop the EuroMaidan revolution and Ukraine's subsequent geopolitical reorientation. Without the EuroMaidan, Crimea would still be part of Ukraine. Current tensions between Russia and the West thus relate mostly to the unsuccessful management of the post-Cold War environment in the European and Mediterranean neighborhoods. These features have nothing to do with the notion of fascism.

\section{RUSSIAN STATE STRUCTURES AND THE RADICAL RIGHT}

Another argument used to claim that Russia is fascist is the presence of far-right groups (Shenfield, 2001; Laqueur, 1993; Likhachev, 2002; Reznik, 1996). Yet Russia is in no way unique in having a fringe element of its society that is inspired by extreme right arguments, with or without references to historical fascism per se. Not only can these groupuscules not enter the legal political game, but their sociological basis remains difficult to grasp. Compared to the United States, for instance, where such groups can rely on deeply anchored traditions of slavery and segregation and on genuine constituencies supporting such a worldview, this is not the case in Russia.

The Russian authorities have by turns repressed, marginalized, adopted a laissez-faire policy towards, and co-opted these grassroots radical-right initiatives, depending on the broader context. Yet that interplay is in fact much more complex because the Russian state is composed of a plurality of actors and "spaces." One can discern approximately a dozen high-level political figures who, in one way 
or another, play powerbroker roles by trying to promote, support, protect, or link radical right figures to state authorities. Two groupsthe segments of the Church under Bishop Tikhon's personal leadership and several clusters of senior military figures connected either to the Defense Ministry or to the security services-seem supportive too. Yet, this list represents only a minimal portion of Russian political elites as a whole. That figures such as Dugin can express themselves without being repressed is a proverbial exception. The fascist "tree" constitutes a very small percentage of Russia's ideological forest, and an excessive focus on peripheral characteristics obscures other ideologies that are available for consumption and that celebrate Russia's uniqueness in more traditional ways by emphasizing national history and culture, Orthodoxy, or some form of Soviet nostalgia.

Classical fascism in the sense of references to historical European fascism or white supremacy remains despised by Russian public opinion and largely repressed by Russian state bodies. What I call "parafascism," i.e., culturally Russified doctrines such as Black Hundreds, Eurasianism, National Bolshevism, mystical Stalinism, that may share some conceptual features related to fascism-belief in a meta-ideology and an enlightened elite, call for mass indoctrination and state violence, and utopia of the nation's regeneration through war-develop more easily. They are given the right to exist as radical ends of a wider spectrum of acceptable doctrines considered as part of the classic stock of Russian nationalism or Russian conservatism: with Black Hundreds as the radical end of the continuum of rehabilitation of tsarism, Eurasianism as the radical end of the continuum of belief in Russia as the pivot of Eurasia, mystical Stalinism and National Bolshevism as the radical end of the continuum of nostalgia for the Soviet greatness.

These doctrines, which have been allowed to exist thanks to some powerful patrons, are nonetheless outside of the mainstream of what the Presidential Administration and the Russian government promote at the everyday level of governmentality. Russia's ideational mainstream relies on a much more conventional and consensual base combining Soviet nostalgia for Brezhnev's time, critiques of the 1990s, and calls for 
a new world order that would challenge supposed Western hypocrisy and moral decadence. At the same time, the official line continues to refer to Europe as a civilizational cradle epitomizing a superior culture and quality of life (Engström, 2020), and to claim acceptance of modernity/modernization/globalization as the "normalcy" of every country in the 21 st century. Cultivating doctrinal plurality, blurriness, and the implicit, this mainstream thinks of ideologies within a market-based logic: contradictory ideational products are crafted for each microtargeted audience in order to secure the largest possible consensus around the regime.

If there is an overarching mainstream ideological trend to identify, it is illiberalism-a denunciation that holds that liberalism is now "obsolete" and has "outlived its purpose," as Putin declared in 2019 (Barber, Foy and Barker, 2019), and a return to an ideology of sovereignty-national, economic and cultural-moral sovereignty. This illiberalism should not be conflated with classical fascism or parafascism. It is not a reactionary ideology calling for a return to the past, but rather a postmodern (and postliberal) conception, attuned to the current worldwide doubts about globalization. Nor is it a utopian, revolutionary ideology hoping to bring about a tabula rasa to rebuild a new mankind, which is a key component of fascism. On the contrary, it asserts the need for a more conventional nation-state providing welfare services and a collective national identity that would be less cosmopolitan and less focused on individual and minority rights. Moreover, the Putin regime continues to adhere to a pretty orthodox liberal economic policy and (generally) tolerates liberal personal (if not political) freedoms.

The same can be said of the Russian state's support for the European far right. These Russian-European connections are both a marriage of convenience and a reflection of deeper long-term ideological alliances (Shekhovtsov, 2017). They are marriages of convenience because the Kremlin has no interest in associating itself with groups that are too radical in their ideology or too marginalized in their own society, sensibly preferring to target mainstream parties that may one day become part of the government. Still, these alliances 
are too fundamental to be purely tactical. They also rely on deep, shared ideological foundations. Their enemies are clearly identified: the world liberal order, the "loose consensus" of parliamentary democracy, the EU supranational construction, and what they call cultural Marxism, i.e., individualism and the promotion of feminism and minority rights. In a matter of years, Moscow has thus succeeded in framing Russophilia and Euroscepticism as two sides of the same coin, thereby positioning Russia as Brussels' and Washington's opposite-a fair analysis of Western weaknesses and internal contradictions.

At a time when the Western media tends to hype Russia's influence on the American and European domestic landscapes, it is worth arguing that, if the rise of far-right and illiberal narratives and parties in Europe and the U.S. is undisputable, the reasons are deeply domestic and embedded in their respective social fabrics. Russia plays an external role: it takes advantage of these new voices, consorts with them, and tries to amplify them, but it did not birth this homegrown dynamic and has no realistic influence over it. Russia acts not as a societal transformer, but rather as an echo chamber of European and American societies' own doubts and transformations.

\section{WHERE IS "FASCISM" LOCATED IN RUSSIA?}

Out of the array of core components that qualify a regime as fascist, Russia displays only one: a constituted paramilitary culture directly supported by state institutions. The sociology of this militia subculture has yet to be written. Composed of several hundred thousand activists, it is far from marginal. The new National Guard counts about 250,000 people; the private security industry comprises around 23,000 registered firms employing about 700,000 people (Rosgvardiya, 2017). The Cossack troops working under the state umbrella represent about 100,000 people. About 400,000 young people participated in one way or another in Youth Army (Gershkovich, 2019), and several hundred thousand participated in a larger network of patriotic paramilitary training and extreme sport clubs. To this should be added numerically smaller movements such as the Orthodox Sorok Sorokov, 
politicized biker clubs such as the Night Wolves, and a broader net of war veteran associations very active in the humanitarian and paramilitary domain.

The rise of security services and the revival of youth military training nurture the recreation of a traditional form of masculinity that is shaped by bodily training, male camaraderie, a sense of sacrifice for the nation, the ability to accept pain, and, in some cases, the idea of regeneration through violence. In this environment, playing with weapons is an ersatz phallic exercise. On this auspicious soil, paramilitary groups, whose ideological language finds itself at ease with the fascist imaginary and body language aesthetics, can prosper.

This paramilitary world combines references both to military and security services and to the criminal world. Born out of the zona realm - the penitentiary system, from Gulag to classic prisons-gang culture has indeed innervated late Soviet and post-Soviet culture, especially in cinematography: criminal slang has become a new lingua franca, violence has long been seen as a path to success, and brotherhood and illicit codes of justice are valued. This gang culture has penetrated the law enforcement and security service agencies (Galeotti, 2018, Stephenson, 2017) and has thus become part of mainstream culture.

Putin's personal image-making has also contributed to the widespread acceptance of gendered clichés pertaining to male values and the need for men to defend society as an extended family. The advancement of Russian and Asian martial arts has been one of Putin's most enduring pet projects. This half-public, half-underground world of sambo and MMA (mixed martial arts) often exhibits an aesthetic inspired by fascism and is active as a recruitment pool for young people to join paramilitary structures. The difficulty of reinvesting masculinity in a post-Soviet context-the same can be said about the relationship between a challenged masculinity and far right vigilantism in the U.S. - thus constitutes a still underexplored field that is essential to understanding the attraction to some aspects of fascist ideology and its body aesthetic in today's Russia. 


\section{CONCLUSION: FASCISM AS THE DRIVER BEHIND RUSSIA'S INCLUSION OR EXCLUSION IN EUROPE}

Central and Eastern European countries want their feeling of belonging to Europe to be more secured, and their memory of the second half of the 20th century be better taken into consideration-these claims are more than legitimate. Crafting new historiographies for the nation is never easy, especially when one has to reintegrate the contradictory segments of the past: how do they give the floor to their citizens who chose to collaborate with Nazi Germany as well as those who defended the Soviet regime? How do they build nationhood in which the shades of the past can be reflected adequately, with room for "collaborationists" as well as for communist "fellow travelers" and antifascist movements?

Presenting Russia as an absolute Other threatening Europe's ontological identity is not a solution. Beyond historiographical and memorial issues, the politicization of the past poses risks. Relativizing and trivializing the Nazi Holocaust to make Russia appear as an equal evil is a dangerous political and moral game. It instrumentalizes the anti-totalitarian philosophy to promote geopolitical (NATO expansion) as well as political and economic (neoliberalism) goals. Not that these are illegitimate, but they should conquer hearts and minds transparently and compete with other legitimate visions of the world order (for instance more leftist), without hiding themselves under the mask of fighting an artificial foil embodied by Putin's Russia. One has to point out the irony that the portrayal of Russia as a totalitarian enemy of the West is being driven in part by the governments of Poland and the Baltic states, which are far more ethno-nationalist than Putin's regime. Moreover, the U.S. has been supporting far more authoritarian regimes than Russia-Saudi Arabia or Sisi's Egypt, for instancewithout casting them in essentialist terms as foes of the West.

On the other hand, while the Ribbentrop-Molotov Pact can be justified in strategic terms in the pre-war context, Russia's reluctance to offer a mea culpa for Stalinist crimes poses a problem, both domestically for the difficulties of the authorities to apologize for state violence, and internationally in not recognizing the mass atrocities committed in occupied territories during the war. The regime's strategy 
has been to downplay tensions around interpreting this key moment of Soviet history and to normalize it. As Maria Lipman thoroughly captures, the Kremlin chose reconciliation over truth (Lipman, 2017). For an external observer or historian, this may seem the wrong choice, but it has been seen as the right calculus for a head of state taking power after a decade of deep divisions. Yet it does not help Moscow's stature on the international scene.

The fascism label has thus become a central element of the difficult dialogue between Russia and Central and Eastern European countries. Their memorial conflict has gradually expanded to reach out some European institutions and spread in some academic or para-academic circles. The othering of Russia by the West still relies mostly on denouncing the country as authoritarian, corrupt, and kleptocratic, while Russia mostly accuses the West of normative imperialism and fake idealism. In this tense framework, the accusation of fascism has found its niche at each extreme side. It remains a latent discursive tool that could be mobilized in the future to further either side's geopolitical agendas, thereby making what is already a dangerous conflict more volatile and intractable.

I interpret these contradictory positions as evidence of a gulf in situated identities. For Russia, the disruption of the agreed-upon European political order results from the EU and NATO expansion into the post-Soviet space, and from a "revisionist" stance on the new European order. In this battle, Moscow positions itself as a conservative power, defending the discursive status quo to freeze narratives on the Yalta Order and the Second World War and their consequences in the face of post-Cold War revisionists who want to change them. For the West, Russia is responsible for disrupting the European order by annexing Crimea and going to war with Ukraine in Donbass, and more globally by no longer accepting the tacit agreements made in the 1990s and allowing former Soviet states to move away from its sphere of influence.

Both the West and Russia are therefore impervious to each other's arguments, as they relate to different historical points of reference. For Russia, "normalcy" refers to the Cold War decades, which gave 
the country the status of respected great power consulted on all major international issues, deeply influential on the European scene and considered the victorious ally of the United States against fascism. For the West, "normalcy" refers to the early 1990s-a Russia that aligned with the West's main geopolitical interests, did not oppose EU expansion, was very critical of its Soviet past, and wanted to follow the European path (Sakwa, 2017, Krickovic and Weber, 2018).

This inability to refer to the same "normalcy" explains the ambivalent dialogue between the notion of conservatism and that of fascism. In the Russian vision, today's fascists are those who want to destroy Europe: those who deny the Yalta order by equating Communism with Nazism and those who challenge classical Western civilization with postmodern theories such as cosmopolitanism (negating national identities), minorities' rights (negating traditional values), and the right to humanitarian intervention (negating state sovereignty). Conservatives are those who want to rescue the "real" Europe: those who promote Christian values, defend classical Western civilization (both in the sense of Antiquity and in the sense of the Westphalian order of state sovereignty), and support the Yalta order and a conventional reading of the Soviet victory in the Second World War. In this Weltanschauung, the European far-right forces that Russia courts find themselves in the conservative camp, not the fascist one, therefore allowing for a strategic alliance with them: this is what the Russian media imply when, for instance, they present Marine Le Pen as the heir of de Gaulle's worldview and not as a representative of the European far right.

Mastering the label of "who is fascist" thus decides what the ideal Europe should be like. If Russia is fascist-if the Putin regime can be typologized as fascist, or if the Soviet past that the Kremlin does not want to denounce is the equivalent of Nazism-then Russia is to be excluded from Europe and portrayed as its antithesis, the constituent Other of all the values embedded in the notion of Europe: liberalism, democracy, multilateralism, transatlantic commitment. If, on the contrary, as Moscow declares, Europe is once again becoming "fascist"-if the ideological status quo on the 1945 victory is contested 
and Europe's so-called traditional values are under attack-then Russia points out a way ahead for the "real" Europe, Christian, conservative, geopolitically continental, and nation-centric, to recover. The current fight to identify who is fascist is thus a struggle to define the future of Europe, and it is the key question that adjudicates between Russia's inclusion or exclusion.

\section{References}

Barbashin, A. and Thoburn, H., 2014. Putin's Brain: Aleksandr Dugin and the Philosophy Behind Putin's Invasion of Crimea. Foreign Affairs, 31 March

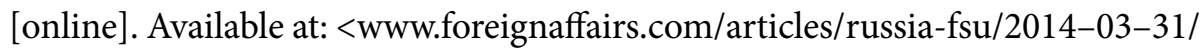
putins-brain $>$ [Accessed 23 September 2020].

Barbashin, A. and Thoburn, H., 2015. Putin's Philosopher: Ivan Ilyin and the Ideology of Moscow's Rule. Foreign Affairs, 20 September [online]. Available at: <www.foreignaffairs.com/articles/russian-federation/2015-09-20/putinsphilosopher> [Accessed 23 September 2020].

Barber, L., Foy, H. and Barker, A., 2019. Vladimir Putin Says Liberalism Has 'Become Obsolete.' Financial Times, 27 June [online]. Available at: <www.ft.com/ content/670039ec-98f3-11e9-9573-ee5cbb98ed36> [Accessed 23 September 2020].

Brzezinski, Z., 2004. Moscow's Mussolini. The Wall Street Journal, 20 September [online]. Available at: <www.wsj.com/articles/SB109563224382121790> [Accessed 23 September 2020].

Camus, J. and Lebourg, N., 2017. Far Right Politics in Europe. Cambridge, MA: The Belknap Press of Harvard University Press.

Darden, K., 2018. Keeping the 'New Cold War' Cold: Nuclear Deterrence with U.S. and Russian Nuclear Force Modernization. PONARS Eurasia Policy Memo, No. 530 (May). Available at: <www.ponarseurasia.org/memo/keeping-new-coldwar-cold-nuclear-deterrence-us-and-russian-force-modernization $>$ [Accessed 23 September 2020].

Engström, M., 2020. Re-Imagining Antiquity: The Conservative Discourse of 'Russia as the True Europe' and Kremlin's New Cultural Policy. In: Kåre Johan Mjör and Sanna Turoma (eds.) Russia as Civilization: Ideological Discourses in Politics, Media, and Academia. Routledge. 
Galeotti, M., 2018. The Vory: Russia’s Super Mafia. New Haven: Yale University Press.

Gershkovich, E., 2019. Russia's Fast-Growing 'Youth Army' Aims to Breed Loyalty to the Fatherland. The Moscow Times, 17 April [online]. Available at: <www.themoscowtimes.com/2019/04/17/russias-fast-growing-youth-armyaimst-to-breed-loyalty-to-the-fatherland-a65256> [Accessed 23 September 2020].

Griffin, R., 1991. The Nature of Fascism. Houndmills, Basingstoke: Palgrave Macmillan.

Hosaka, S., 2019 Welcome to Surkov's Theater: Russian Political Technology in the Donbas War. Nationalities Papers, 47, No. 5, pp.750-773. DOI: doi. org/10.1017/nps.2019.70.

Knott, E., 2017. Quasi-Citizenship as a Category of Practice: Analyzing Engagement with Russia's Compatriot Policy in Crimea. Citizenship Studies, 21(1), pp.116-135. DOI: doi.org/10.1080/13621025.2016.1252714.

Kolstø, P., 2016. The Ethnification of Russian Nationalism. In: Pål Kolstø and Helge Blakkisrud (eds.) The New Russian Nationalism. Edinburgh University Press, pp.18-45.

Krickovic, A. and Weber, Y., 2018. Commitment Issues: The Syrian and Ukraine Crises as Bargaining Failures of the Post-Cold War international order. Problems of Post-Communism, 65(6), pp.373-384.

Laqueur, W., 1993. Black Hundred: The Rise of the Extreme Right in Russia. HarperCollins.

Laruelle, M. 2018. Russian Nationalism. Imaginaries, Doctrines and Political Battlefields. London: Routledge.

Laruelle, M., 2015. Russia as a 'Divided Nation', from Compatriots to Crimea: A Contribution to the Discussion on Nationalism and Foreign Policy. Problems of Post-Communism, 62(2), pp. 88-97. DOI: doi.org/10.1080/10758216.2015.1 010902.

Laruelle, M., 2015. The 'Russian World': Russia's Soft Power and Geopolitical Imagination. Washington, DC: Center on Global Interests.

Laruelle, M., 2015. The Three Colors of Novorossiya, or the Russian Nationalist Mythmaking of the Ukrainian Crisis. Post-Soviet Affairs, 32(1), pp.55-74. DOI: doi.org/10.1080/1060586X.2015.1023004. 
Laruelle, M. 2016. Misinterpreting Nationalism: Why Russkii Is Not a Sign of Ethnonationalism. PONARS Eurasia Policy Memo, No. 416 (January). Available at: <www.ponarseurasia.org/memo/misinterpreting-nationalism-russkiiethnonationalism $>$ [Accessed 23 September 2020].

Laruelle, M., and Karnysheva, M., 2020. Memory Politics and the Russian Civil War: Reds versus Whites. Bloomsbury.

Lassila, J., 2014. The Quest for an Ideal Youth in Putin's Russia II, The Search for Distinctive Conformism in the Political Communication of Nashi, 2005-2009. Stuttgart: Ibidem-Verlag.

Likhachev, V., 2002. Natsizm v Rossii [Nazism in Russia]. Moscow: Panorama.

Lipman, M., 2017. Putin's Nation-Building Project Offers Reconciliation Without Truth. Open Democracy, 12 April [online]. Available at: <www.opendemocracy. net/od-russia/maria-lipman/putins-nation-building-project-reconciliationwithout-truth $>$ [Accessed 23 September 2020].

Motyl, A. J., 2016. Putin's Russia as a Fascist Political System. Communist and Post-Communist Studies, 49(1), pp.25-36. DOI: doi.org/10.1016/j. postcomstud.2016.01.002.

Mudde, C., 2019. The Far Right Today. Polity.

Orwell, G., 1946. Politics and the English Language [online]. Available at: <www. orwell.ru/library/essays/politics/english/e_polit> [Accessed 23 September 2020].

Paxton, R. O., 2004. The Anatomy of Fascism. New York: Random House Publishing.

Pinkham, S., 2018. Zombie History: Timothy Snyder's Bleak Vision of the Present and Past. The Nation, 3 May [online]. Available at: <www.thenation. com/article/timothy-snyder-zombie-history/> [Accessed 23 September 2020].

Pravozaschitny Tsentr Memorial, n.d. Spisok politzaklyuchennyh (bez presleduemyh za religiyu) [Political Prisoners List (without Persecuted for Religious Beliefs)] [online]. Available at: $<$ memohrc.org/ru/pzk-list $>$ [Accessed 23 September 2020].

Pravozaschitny Tsentr Memorial, n.d. Spisok politzaklyuchennyh presleduemyh $z a$ religiyu [List of Political Prisoners Persecuted for Religious Beliefs] [online]. Available at: $<$ memohrc.org/ru/aktualnyy-spisok-presleduemyh-v-svyazi-srealizaciey-prava-na-svobodu-veroispovedaniya $>$ [Accessed 23 September 2020]. 
Putin, V., 2012. Russia: The Ethnicity Issue. Nezavisimaia gazeta, 23 January [online]. Available at: <archive.premier.gov.ru/eng/events/news/17831/> [Accessed 23 September 2020].

Putin, V., 2014. Obrashchenie Prezidenta Rossiīskoī Federatsii [Address of the President of the Russian Federation]. Kremlin.ru, 18 March [online]. Available at: $<$ kremlin.ru/events/president/news/20603 $>$ [Accessed 23 September 2020].

Putin, V., 2015. Poslanie Prezidenta Federal'nomu Sobraniyu [Address of the President to the Federal Assembly]. Kremlin.ru, 3 December [online]. Available at: $<$ http://kremlin.ru/events/president/news/50864> [Accessed 23 September 2020].

Putin, V., 2019. Zasedanie Diskussionogo Kluba 'Valdai' [Valdai Discussion Club Session]. Kremlin.ru, 18 October [online]. Available at: <kremlin.ru/ events/president/news/61719> [Accessed 23 September 2020].

Putin, V., 2020. Vladimir Putin: The Real Lessons of the 75th Anniversary of World War II. The National Interest, 18 June [online]. Available at: $<$ nationalinterest.org/feature/vladimir-putin-real-lessons-75th-anniversaryworld-war-ii-162982> [Accessed 23 September 2020].

Radio Free Europe/Radio Liberty (RFE/RL), 2005. World: James Woolsey, Former CIA Director, Speaks to RFE/RL at Forum 2000. RFE/RL, 10 October [online] Available at: <www.rferl.org/content/article/1062001.html $>$ [Accessed 23 September 2020].

Reznik, S., 1996. The Nazification of Russia: Antisemitism in the Post-Soviet Era. Washington, D.C.: Challenge Publications.

Robinson, P. 2019. Russian Conservatism. DeKalb: Northern Illinois University Press.

Robinson, P. 2020. Russia's Emergence as an International Conservative Power. Russia in Global Affairs, 18(1), [online]. Available at: <https://eng.globalaffairs. $\mathrm{ru} /$ articles/russias-conservative-power/> [Accessed 23 September 2020]. DOI: 10.31278/1810-6374-2020-18-1-10-37.

Rosgvardiya, 2017. Kontseptsiia Razvitiia Vnevedomstvennoī Okhrany na period 2018-2021 godov i dalee do 2025 goda [Concept of the Development of Extra-Departmental Guard for the Period of 2018-2021 and further to 2025]. [online]. Available at: < rosgvard.ru/ru/page/index/koncepciya-razvitiyavnevedomstvennoj-oxrany $>$ [Accessed 23 September 2020].

Rucker, P., 2014. Hillary Clinton Says Putin's Actions Are Like 'What Hitler Did Back in the 30s'. Washington Post, 5 March [online]. Available at: <www. 
washingtonpost.com/news/post-politics/wp/2014/03/05/hillary-clintonsays-putins-action-are-like-what-hitler-did-back-in-the-30s/> [Accessed 23 September 2020].

Sakwa, Richard, 2017. Russia Against the Rest: The Post-Cold War Crisis of World Order. Cambridge; Cambridge University Press.

Semenov, A., 2020. Team Navalny and the Dynamics of Coercion: The Kremlin's Reaction to Aleksei Navalny's 2018 Presidential Campaign. PONARS Eurasia Policy Memo, No. 655 (June). Available at: <www.ponarseurasia.org/memo/ team-navalny-and-dynamics-coercion-kremlin-reaction-alexei-navalny-2018presidential> [Accessed 23 September 2020].

Semenov, A. and Bederson, V., 2020. Organizational Resilience: Russian Civil Society in the Times of COVID-19. PONARS Eurasia Policy Memo, No. 663 (July). Available at: <www.ponarseurasia.org/memo/organizational-resiliencerussian-civil-society-times-covid-19> [Accessed 23 September 2020].

Shekhovtsov, A., 2017. Russia and the Western Far Right: Tango Noir. London: Routledge.

Shenfield, S. D., 2001. Russian Fascism: Traditions, Tendencies and Movements. New York and London: M.E. Sharpe.

Sherlock, T., 2016. Russian Politics and the Soviet Past: Reassessing Stalin and Stalinism under Vladimir Putin. Communist and Post-Communist Studies, 49(1), pp.45-59.

Shevel, O., 2012. The Politics of Citizenship Policy in Post-Soviet Russia. Post-Soviet Affairs 28(1), pp. 111-147. DOI: https://doi.org/10.2747/1060586X.28.1.111.

Snyder, T., 2014. Putin's New Nostalgia. The New York Review, 10 November [online]. Available at: <www.nybooks.com/daily/2014/11/10/putin-nostalgiastalin-hitler/> [Accessed 23 September 2020].

Snyder, T., 2016. How a Russian Fascist Is Meddling in America's Election. The New York Times, 20 September [online]. Available at: <www.nytimes. com/2016/09/21/opinion/how-a-russian-fascist-is-meddling-in-americaselection.html?mcubz=0 $>$ [Accessed 23 September 2020].

Stephenson, S., 2015. Gangs of Russia: From the Streets to the Corridors of Power. Ithaca: Cornell University Press.

Stephenson, S., 2017. It Takes Two to Tango: The State and Organized Crime in Russia. Current Sociology, 65(3), pp.411-426. DOI: doi.org/10.1177/0011392116681384. 
Suslov, M. and Uzlaner, D. (eds.), 2019. Contemporary Russian Conservatism: Problems, Paradoxes, and Perspectives. Brill: Eurasian Studies Library, Vol. 13.

Suslov, M., 2018. 'Russian World' Concept: Post-Soviet Geopolitical Ideology and the Logic of 'Spheres of Influence.' Geopolitics, 23(2), pp.330-353. DOI: doi. org/10.1080/14650045.2017.1407921.

Toal, G., 2019. Near Abroad: Putin, the West, and the Contest Over Ukraine and the Caucasus. Oxford: Oxford University Press, 2019.

van Herpen, M., 2013. Putinism: The Slow Rise of a Radical Right Regime in Russia. New York: Palgrave Macmillan.

Wodak, R., de Cillia, R., Reisigl and Liebhart, K., 1999. The Discursive Construction of National Identity. Edinburgh: Edinburgh University Press.

Yusupova, G., 2019. Why Ethnic Politics in Russia Will Return. PONARS Eurasia Policy Memo, No. 584 (March). Available at: <www.ponarseurasia.org/memo/ why-ethnic-politics-russia-will-return $>$ [Accessed 23 September 2020]. 